\title{
Everted Intestinal Sacs As In vitro Model For Assessing Absorptivity Of L- Histidine Under The Effect Of Aspirine And Gum Acacia In Male Rats
}

\author{
Mahmoud Rabeh Mahmoud \\ Zoology Department, Faculty Of Science, Zagazig University, Egypt
}

\begin{abstract}
The purpose of this study was to characterize intestinal permeability changes over a range of physiologically relevant intestinal injury. The experiments were performed in 80 rats subdivided into four groups as aspirin ( $400 \mathrm{mg} / \mathrm{kg} \mathrm{b.w.),} \mathrm{gum} \mathrm{Acacia} \mathrm{(} 1 \mathrm{~g} . / \mathrm{day})$ and aspirin with gum Acacia groups for 21 days compared with control group. Relative reabsorption of LHistidine was greater $(\mathrm{p}<0.001)$ in the aspirin in $10 \mathrm{~min}$ of incubation compared with that of the control rats. In aspirin in combination with gum Acacia, the relative reabsorption were significantly $(\mathrm{p}<0.001)$ decrease in 10,20 and $30 \mathrm{~min}$. of incubation compared with that of the control rats. Moreover, the relative reabsorption of L-histidine was significantly $(p<0.01)$ reduced by the aspirin at $45 \mathrm{~min}$ of time of the incubation buffer compared with that of the control. However, gum acacia treatment was increased at $10 \min (p<0.01), 30 \mathrm{~min}(\mathrm{p}<0.01)$ and $45 \mathrm{~min}(\mathrm{p}<0.001)$ respectively compared with that of the control rats. Relative reabsorption of L-histidine record a nonsignificant increase of aspirin at $20 \mathrm{~min}$ and $30 \mathrm{~min}$ of incubation compared with that of the control. Gum and aspirin with gum at $20 \mathrm{~min}$ and $45 \mathrm{~min}$ of incubation resulted an increase and decrease in relative reabsorption of L-histidine respectively compared with that of the control. Aspirin and aspirin in combination with gum acacia treatment increased body, intestinal weights and mucosal total protein significantly with percent changes ranged from $8 \%$ to $40 \%$ compared with that of the control. On the other hand, gum treatment decreased body, intestinal weights and mucosal total protein significantly with percent changes ranged from $8 \%$ to $35 \%$ compared with that of the control. These results demonstrated that L-histidine is actively taken up by a gum Acacia system in intestinal everted sac mechanism of rat with energy supplied by glucose and $\mathrm{Na}^{+}$in incubation buffer. Moreover, aspirin system had an inhibitory effect on L-histidine uptake in $45 \mathrm{~min}$ of incubation, indicating the saturation by L-histidine in first ten minuts of incubation. Also, these results provide evidence the uptake of L-histidine into rat intestine was not reduced at all by the treatment of aspirin. These results suggest that the uptake of L-histidine by intestinal everted sac of rat has different characteristics of aspirin with gum compared with that of the control in respect to relative reabsorption of Lhistidine.
\end{abstract}

Key words: everted sac, L-histidine,Aspirin, Gum arabic, relative reabsorption.

\section{Introduction}

Intestinal absorption of peptides were performed with the everted small intestine by Mizuma et al.,1992. The mucosa of gastrointestinal (GI) tract protects the internal gut lumen from bacteria and bacterial product such as endotoxin (Gisolfi, 2000). This protective feature of the gastrointestinal mucosa is referred to as GI barrier. Dysfunction of this barrier leads to an increase in intestinal permeability, which involves the passive, nonmediated diffusion of both small and large molecules from GI lumen to the blood (Travis and Menzies,1992). Increased intestinal permeability can result from numerous pathophysiological conditions including hemorrhage and endotoxemia (Salzman et al.,1994; Unno et al.,1997; Anand et 
al.,2004) and has been observed after strenuous exercise (Pals et al.,1997) and exercise combined with nonsteroidal antiinflammatory drug use (Lambert et al.,2001; Ryan et al.,1996; Cui et al.,2004).

Aspirin, by virtue of its ability to irreversibly acetylate the cyclooxygenase enzyme, is capable of inhibiting both prostacyclin $\left(\mathrm{PGI}_{2}\right)$ production by endothelial cells (Abdel Salam et al.,1995). and thromboxane $\mathrm{A}_{2}\left(\mathrm{TXA}_{2}\right)$ synthesis by platelets(Buist, 1984).At low doses of aspirin an antithrombotic environment can be created by the selective inhibition of $\mathrm{TXA}_{2}$ (Dihlmann et al.,2001). Others would argue that both platelet and endothelial cyclooxygenases are equally inhibited, particularly after high doses or single administrations, or that any selectivity is a function of the route of administration (Thomas et al.,1993). Sansom et al.(2001) showed that dietary aspirin exposure can suppress tumorigenesis in the murine intestine and the mammary gland. Aspirin is a drug that reduces swelling, pain, and fever. In recent years, long-term low-dose aspirin has been recommended to reduce the risk of heart attacks and strokes. In the future aspirin may be recommended to reduce the risk of some cancers. Reye's syndrome, a rare but serious illness affecting children and teenagers, has been associated with aspirin use. To prevent Reye's syndrome, people should consult their doctor and/or pharmacist before giving aspirin, aspirin-containing products, or herbs containing salicylates to children and teenagers (Rees et al., 1979).

Gastrointestinal (GI) bleeding is a common side effect of taking aspirin. A person with aspirin-induced GI bleeding may not always have symptoms (like stomach pain) or obvious signs of blood in their stool. Such bleeding causes loss of iron from the body. Long-term blood loss due to regular use of aspirin can lead to iron-deficiency anemia. Lost iron can be replaced with iron supplements. Iron supplementation should be used only in cases of iron deficiency verified with laboratory (Holzer et al.,1989). Taking aspirin has been associated with increased loss of vitamin $\mathrm{C}$ in urine and has been linked to depletion of vitamin C. People who take aspirin regularly should consider supplementing at least a few hundred milligrams of vitamin $C$ per day. Such an amount is often found in a multivitamin (Coffey and Wilson,1975). Non-steroidal anti-inflammatory drugs (NSAIDs) are the most prescribed drugs worldwide which attests to their efficacy as analgesics, and anti-inflammatory and anti-pyretic agents. The main concern with this group of drugs is the frequency and severity of their gastrointestinal side effects (Daneshmend et al.,1991) . Increased loss of folic acid in urine has been reported in rheumatoid arthritis patients (Buist,1984). Reduced blood levels of the vitamin have also been reported in people with arthritis who take aspirin (Alter et al.,1971). Also, Gastrointestinal (GI) bleeding is a common side effect of taking aspirin. A person with aspirin-induced GI bleeding may not always have symptoms (like stomach pain) or obvious signs of blood in their stool. Such bleeding causes loss of iron from the body. Long-term blood loss due to regular use of aspirin can lead to iron-deficiency anemia. Lost iron can be replaced with iron supplements. Iron supplementation should be used only in cases of iron deficiency verified with laboratory tests. Furthermore, Intake of 3 grams of aspirin per day has been shown to decrease blood levels of zinc (Ambanelli,1982). Aspirin appeared to increase loss of zinc in the urine in this study, and the effect was noted beginning three days after starting aspirin. The pathogenesis of intestinal damage is incompletely understood. It is generally accepted that the early pathogenic events include a "topical" phase in addition to the inhibition of cyclooxygenase, followed by a multistage pathogenic event in which intestinal permeability, luminal contents, neutrophils, and the microcirculation all play a role in the development of inflammation and ulcers (Whittle,1992a ; Wallace,1994; Rainsford \& Whitehouse, 1982; Somasundaram et al.,1995). The importance of inhibition of cyclooxygenase in the damage induced by NSAIDs has been clearly documented (Whittle,1992b; Fiorucci et al., 2004). Nevertheless, it is 
possible to inhibit cyclooxygenase selectively without inducing intestinal damage (Levine et al.,1988; Ligumski et al.,1983; Ivey et al.,1980; Langenbach et al.,1995) . Furthermore, disruption of the prostaglandin synthase- 1 gene coding for cyclooxygenase-1 in mice, with resulting mucosal prostaglandin concentrations of less than $1 \%$ of that of controls, is not associated with gastrointestinal pathology (Langenbach et al.,1995). In the stomach changes in drug formulation as enteric coating, rectal administration (Ivey et al.,1980; Rainsford, 1989) and abolishing gastric acid secretion induced damage (Daneshmend et al.,1991) presumably by limiting the gastric absorption of the drug greatly increase tolerability of NSAIDs in the short term. This suggests that the "topical" action of NSAIDs may be an important co-factor in the initiation of the damage (Whittle,1992a,b). The "ion trapping" hypothesis which postulates that accumulation of NSAIDs in intestinal epithelial cells depends largely on the interaction of the acidity of the NSAID (pKa) and luminal $\mathrm{pH}$ provides a basis for (along with molecular size, lipid solubility and contact time ) the "topical" action of NSAIDs but not the mechanism (Brookes \& Day, 1991; Brune et al., 1977; Kharasch et al.,2004) . On the other hand, Gums are a high-energy food source composed mainly of water, complex polysaccharides, calcium, and trace minerals as iron, aluminum, silicon, potassium, magnesium, and sodium (Nash,1986). Calcium is important to all animals, especially female callitrichids (tamarins and marmosets) which commonly give birth to twins twice a year. It is during the lactation period that the females are usually impregnated by the male. The calcium-to phosphorus ratio is high in gums which offsets its ratio in insects, which is low. Because all known wild gummivores also include insects in their diet, combining the two, in captivity, may approach a desired nutritional balance and is recommended to avoid the possibility of nitrogen loss and the loss of protein from the body (Nash, 1986; Garber, 1984a; Sussman and Kinzey 1984; Coimbra-Filho, et al., 1978; Moynihan 1976). Furthermore, karaya gum does not disintegrate or decompose appreciably inthe alimentary tract. In a study of 10 dogs, $95 \%$ of the orally administered gum was recovered in the faeces. It absorbs a large quantity of water and therefore acts as a mechanical laxative. It tends to increase faecal nitrogen excretion, does not affect starch digestion in the dogs and does not inhibit the utilization of vitamin A in rats (Ivy \& Isaacs, 1938). Five rats were fed karaya gum in the diet for two years. Three developed enlarged colon and ulceration (Carlson \& Hoelzel, 1948). In another experiment, groups of three rats were fed karaya gum at first at $10 \%$, gradually increasing to $25 \%$ in the diet over their life span. Controls of five and seven animals received low residue diets. No caecal ulceration was found in this experiment (Nash,1986).

Generally, animals that use plant exudates are small bodied, have a high metabolism, and are incapable of storing large amounts of fat. Primary gum-eaters have most, or all, of the following traits: small body size, clawed digits (for vertical clinging at gum sources), long procumbent or semiprocumbent incisors complimented by short lower canines (providing a level gouging/scrapping surface), loss of enamel on the lingual side of the lower incisors complimented by honing upper incisors (providing a sharpening effect that permits gouging or scraping abilities), a V-shaped configuration of the mandibular arch, a long tongue (to reach gums within the plant bark), and an enlarged cecum (to allow for fermentation of the gums) (Fleagle, 1988; Coimbra-Filho and Mittermier,1978; Rosenberger, 1978).

The transport characteristics of Lhistidine through the blood-lung barrier were studied in cultured rat lung microvascular endothelial cells (LMECs). L-Histidine uptake was a saturable process. The addition of metabolic inhibitors [2,4dinitrophenol (DNP) and rotenone] reduced the uptake rate of L-histidine. Ouabain, an inhibitor of $\mathrm{Na}^{+}-\mathrm{K}^{+}$-ATPase, also reduced uptake of L-histidine. Moreover, the initial L-histidine uptake rate was reduced by the substitution of $\mathrm{Na}^{+}$with choline chloride and choline bicarbonate in the incubation buffer (Sakurai et al.,2002). However, the 
plasma membrane of endothelial cells has been shown to be the site of several carriermediated transport systems (Shu et al.,1997; Yeh and Holt ,1986), including those for glucose, monocarboxylic acid, and amino acids. Three amino acids, Lglutamine, L-histidine, and L-asparagine, all of which have a nitrogen in their side group, are the natural substrates for this transporter (Hundal et al.,1987; Kilberg et al.,1980 ). In particular, L-histidine, an essential amino acid, is a precursor of histamine. Histamine initiates transitory increases in endothelial permeability in situ and in vitro (Moy et al.,1996, Wu and Baldwin, 1992). Under in situ conditions, increased permeability is associated with the development of small gaps between adjacent endothelial cells, and restored barrier function is associated with the reapposition of adjacent cells (Leach et al.,1995).

\section{Materials And Methods}

Male adult Sprague-Dawley rats, weighing $170-200 \mathrm{~g}$, were used to study the intestinal absorption of L-Histidine by everted sac technique under the effect of aspirin, gum arabic and their combination. They were kept in a 12:12-h light-dark cycle and fed a standard chow diet ad libitum. Rats were placed on diets containing gum $1 \mathrm{~g}$ per day (Ivy \& Isaacs, 1938) followed by $400 \mathrm{mg} / \mathrm{kg}$ of aspirin (Sansom et al.,2001) for period 21 day . Control rats were placed on normal diet and water ad libtum.

Preparation of the everted sac: The everted sac technique described in detail by (Karasov and Diamond,1983). Rats were killed and open the abdomen by midline incision. Remove the small intestine by cutting each end. The middle small intestine were obtained from the proximal end. Wash the entire length of the small intestine with glucose-saline solution to remove blood, debrise. Insert a narrow glass rod into one end of the intestine. Tie a ligature over the thickened part of the glass rod and evert the sac by gently pushing the rod through the whole length of the intestine. Remove the rod and place the intestine in a glucose-saline solution at room temperature. Tie off $4 \mathrm{~cm}$ length of the intestine with thread and cut an open sac from the main length. Place asecond ligature loosely round the open end of the sac and introduce a blunt needle attached to a syringe.Tighten the loose ligature over the needle and inject $0.4 \mathrm{ml}$ of the Krebs buffer L-glucose solution (in $\mathrm{mM}: 118 \mathrm{NaCl}$, $4.7 \mathrm{KCl}, \quad 25 \mathrm{NaHCO}_{3}, \quad 1.2 \mathrm{CaCl}_{2}$, $1.2 \mathrm{MgSO}_{4}, 11.1$ glucose, $\mathrm{pH}$ 7.4) for the concentration gradient experiments into the sac; tighten the ligature and withdraw the needle. All the ligtures have to be firm enough to prevent leaks but not tight so as damage the tissue. The total surface area of the everted sac of the small intestine were recorded.

L-Histidine transport: Immerse the sac in $15 \mathrm{ml}$ of the $5 \mathrm{mmol} / \mathrm{l}$ histidine $(\mathrm{BDH}$ Chemicals,Ltd poole, England) solution bubbled with $95 \% \quad \mathrm{O}_{2}-5 \% \quad \mathrm{CO}_{2}$, seal the flask and shake for $10 \mathrm{mi} 9 \mathrm{n}$ in $37{ }^{\circ} \mathrm{C}$ water bath. At the end of this time, analyse 0.2 $\mathrm{ml}$ of the solution inside the everted sac(mucosal side) for L-histidine after deproteinization. Repeat with other everted sacs after 20, 30 and 45 minutes.

Histidine measurement: Mix $1 \mathrm{ml}$ of the weak acetic acid solution with $0.1 \mathrm{ml}$ of test solution in a test tube, cover with a marble amd place the tubes in a boiling water bath for $10 \mathrm{~min}$. Cool and add distilled water to give final volum of $2.5 \mathrm{ml}$ and centrifuge. Take $1 \mathrm{ml}$ of deproteinized solution, add $0.2 \mathrm{ml}$ of sulphanilic acid $(1 \mathrm{~g} / \mathrm{l}$ in $1 \mathrm{~mol} / \mathrm{l}$ $\mathrm{HCl}$ ). Shake the tube and leave stand for 5 min with shaking. Add $0.6 \mathrm{ml}$ of sodium carbonate solution7.5 $(\mathrm{g} / 100 \mathrm{ml})$ and shake vigorousy for about 10 second. Add $2 \mathrm{ml}$ of ethanol(20\%) and $1 \mathrm{ml}$ of water, mix thoroughly and read at $498 \mathrm{~nm}$ against distilled water after $30 \mathrm{~min}$. Calculate the concentration of histidine present by reference to a standard curve of histidine concentration using $2 \mathrm{ml}$ of $0.15 \mathrm{mmol} / 1$ histidine instead of the $2 \mathrm{ml}$ of deproteinized fluid (Fenselau, 1997) . 


\section{Mahmoud Rabeh Mahmoud}

\section{Relative Permeability $=$ \\ Concentration serosal fluid $\mathbf{X}$ Volum serosal fluid $^{\circ}$ mucosal surface area}

Relative permeability: Flattened intestinal sacs were measured for length and width and surface area was calculated. Relative permeability $(\mathrm{mmol} / \mathrm{cm} 2$ mucosal surface Determination of Intestinal total protein: Mucosal intestinal everted loop of known length was scraped with microscopic slide (Sharathchandra et al.,1995). The mucosal scrapings were homogenized in $0.9 \%$ saline and used for protein determination according to the method of Lowry et al.(1951) using bovine serum albumin as thestandard. area) of everted sacs was calculated as transport of the L-histidine into serosal fluid on the basis of the following equation which indicated by (Lambert et al.,2002).

Statistical analysis: All values of tables from (1 to 4) are expressed as means for 5 rats. The uptake data in table (5 and 6) are presented as means $\pm \mathrm{SE}$ of means for 5 rats. Comparisons of data among treated and control groups were carried out using student t'test according to (Snedecor and Cochran, 1969).

Table (1): Concentration of serosal fluid of L-histidine (mmol/l), mucosal surface area $\left(\mathrm{cm}^{2}\right)$ and relative permeability $\left(\mathrm{mmol} / \mathrm{cm}^{2}\right)$ of intestinal everted sac under the effect of aspirin $(400 \mathrm{mg} / \mathrm{kg} \mathrm{b.w.)} \mathrm{and} \mathrm{Gum} \mathrm{(5mg/kg} \mathrm{b.w.)} \mathrm{and} \mathrm{their} \mathrm{combination}$ compared with that of the control male rats at 10 minuts time from the incubation.

\begin{tabular}{|c|c|c|c|c|}
\hline Parameters & Control & Aspirin & Gum & Aspirin + Gum \\
\hline \hline Concentration of serosal fluid (Mean) & 0.039 & 0.0189 & 0.0297 & 0.0174 \\
\hline Mucosal surface area (Mean) & 4.42 & 3.564 & 3.388 & 4.252 \\
\hline Relative reabsorption (mmol/cm2) & 0.00356 & 0.00214 & 0.0035 & 0.00164 \\
\hline
\end{tabular}

Means of five rats.

Table (2): Concentration of serosal fluid of $\mathrm{L}$-histidine (mmol/l), mucosal surface area $\left(\mathrm{cm}^{2}\right)$ and relative permeability $\left(\mathrm{mmol} / \mathrm{cm}^{2}\right)$ of intestinal everted sac under the effect of aspirin $(400 \mathrm{mg} / \mathrm{kg} \mathrm{b.w.)} \mathrm{and} \mathrm{Gum}(5 \mathrm{mg} / \mathrm{kg} \mathrm{b.w.)} \mathrm{and} \mathrm{their} \mathrm{combination}$ compared with that of the control male rats at 20 minuts time from the incubation.

\begin{tabular}{|c|c|c|c|c|}
\hline Parameters & Control & Aspirin & Gum & Aspirin + Gum \\
\hline \hline $\begin{array}{c}\text { Concentration of serosal fluid } \\
\text { (Mean) }\end{array}$ & 0.046 & 0.0341 & 0.0399 & 0.0208 \\
\hline $\begin{array}{c}\text { Mucosal surface area (Mean) } \\
\text { Relative reabsorption } \\
\left(\mathrm{mmol} / \mathrm{cm}^{2}\right)\end{array}$ & 4.472 & 3.44 & 3.538 & 3.84 \\
\hline
\end{tabular}

Means of five rats. 
Table (3): Concentration of serosal fluid of L-histidine (mmol/l), mucosal surface area $\left(\mathrm{cm}^{2}\right)$ and relative permeability $\left(\mathrm{mmol} / \mathrm{cm}^{2}\right)$ of intestinal everted sac under the effect of aspirin $(400 \mathrm{mg} / \mathrm{kg} \mathrm{b.w.)}$ and $\mathrm{Gum}(5 \mathrm{mg} / \mathrm{kg}$ b.w.) and their combination compared with that of the control male rats at $\mathbf{3 0}$ minuts time from the incubation.

\begin{tabular}{|c|c|c|c|c|}
\hline Parameters & Control & Aspirin & Gum & Aspirin + Gum \\
\hline \hline $\begin{array}{c}\text { Concentration of serosal fluid } \\
\text { (Mean } \pm \text { S.E.) }\end{array}$ & 0.056 & 0.0867 & 0.0796 & 0.0275 \\
\hline $\begin{array}{c}\text { Mucosal surface area } \\
(\text { Mean } \pm \text { S.E) }\end{array}$ & 3.63 & 3.992 & 3.32 & 3.926 \\
\hline $\begin{array}{c}\text { Relative } \\
\text { reabsorption }\left(\mathrm{mmol} / \mathrm{cm}^{2}\right)\end{array}$ & 0.0062 & 0.00496 & 0.00996 & 0.00288 \\
\hline
\end{tabular}

Means of five rats.

Table (4): Concentration of serosal fluid of L-histidine (mmol/l) , mucosal surface area $\left(\mathrm{cm}^{2}\right)$ and relative permeability $\left(\mathrm{mmol} / \mathrm{cm}^{2}\right)$ of intestinal everted sac under the effect of aspirin $(400 \mathrm{mg} / \mathrm{kg} \mathrm{b.w.)} \mathrm{and} \mathrm{Gum}(5 \mathrm{mg} / \mathrm{kg} \mathrm{b.w.)} \mathrm{and} \mathrm{their} \mathrm{combination}$ compared with that of the control male rats at 45 minuts time from the incubation.

\begin{tabular}{|c|c|c|c|c|}
\hline Parameters & Control & Aspirin & Gum & Aspirin + Gum \\
\hline \hline $\begin{array}{c}\text { Concentration of serosal fluid } \\
\text { (Mean } \pm \text { S.E.) }\end{array}$ & 0.0664 & 0.0369 & 0.127 & 0.078 \\
\hline $\begin{array}{c}\text { Mucosal surface area } \\
\text { (Mean } \pm \text { S.E) }\end{array}$ & 3.454 & 3.392 & 3.8 & 4.324 \\
\hline $\begin{array}{c}\text { Relative reabsorption } \\
\left(\mathrm{mmol} / \mathrm{cm}^{2}\right)\end{array}$ & 0.0079 & 0.00439 & 0.0137 & 0.0075 \\
\hline
\end{tabular}

Means of five rats. 
Table (5): Relative permeability of intestinal everted sac under the effect of aspirin $(400 \mathrm{mg} / \mathrm{kg} \mathrm{b.w.)}$, Gum $(5 \mathrm{mg} / \mathrm{kg}$ b.w.) and their combination compared with that of the control of male rats at different times from the incubation $(2,4,6$ and 8 minuts). Mean \pm S.E.

\begin{tabular}{|c|c|c|c|c|}
\hline Parameters & $10 \mathrm{~min}$. & 20 min. & 30 min. & $45 \mathrm{~min}$. \\
\hline $\begin{array}{c}\text { control } \\
(\text { Mean } \pm \text { S.E. })\end{array}$ & $\begin{array}{c}0.00356 \pm \\
0.00018\end{array}$ & $\begin{array}{l}0.0043 \pm \\
0.00042\end{array}$ & $\begin{array}{l}0.0062 \pm \\
0.00041\end{array}$ & $\begin{array}{l}0.0079 \pm \\
0.00078\end{array}$ \\
\hline$\%$ Change & - & - & - & - \\
\hline $\begin{array}{c}\text { Aspirin } \\
(\text { Mean } \pm \text { S.E) }\end{array}$ & $\begin{array}{c}0.00214 \pm \\
0.000247 * * *\end{array}$ & $\begin{array}{c}0.0045 \pm \\
0.0059 \text { n.s. }\end{array}$ & $\begin{array}{c}0.00496 \pm \\
0.00074 \text { n.s. }\end{array}$ & $\begin{array}{c}0.00439 \pm \\
0.00041 * *\end{array}$ \\
\hline$\%$ Change & $+39.89 \%$ & $+4.65 \%$ & $-20.00 \%$ & $-44.43 \%$ \\
\hline Gum (Mean \pm S.E.) & $\begin{array}{c}0.0036 \pm \\
0.000115 * *\end{array}$ & $\begin{array}{c}0.00464 \pm \\
0.0006 \text { n.s. }\end{array}$ & $\begin{array}{c}0.00996 \pm \\
0.00091 * *\end{array}$ & $\begin{array}{c}0.0137 \pm 0.00088 \\
* * *\end{array}$ \\
\hline$\%$ change & $+79.77 \%$ & $+7.91 \%$ & $+60.65 \%$ & $+73.42 \%$ \\
\hline $\begin{array}{c}\text { Aspirin + Gum } \\
\text { (Mean } \pm \text { S.E.) }\end{array}$ & $\begin{array}{c}0.00164 \pm \\
0.0001 * * *\end{array}$ & $\begin{array}{c}0.00221 \pm \\
0.000162 * * *\end{array}$ & $\begin{array}{c}0.00288 \pm \\
0.000222 * * *\end{array}$ & $\begin{array}{c}0.0075 \pm \\
0.00089 \text { n.s. }\end{array}$ \\
\hline$\%$ change & $-53.93 \%$ & $-48.60 \%$ & $-53.55 \%$ & $-5.06 \%$ \\
\hline
\end{tabular}

*Significant at $\mathrm{P}<0.05, * *$ high significant at $\mathrm{P}<0.01$, ***very highly significant at $\mathrm{P}<$ 0.001 and n.s. represent a nonsignificant respectively.

Table (6): Body weight $(\mathrm{g})$, Intestinal weight $(\mathrm{g}) / 10 \mathrm{~cm}$ length and Intestinal total protein $(\mathrm{mg}) / \mathrm{g}$ tissue wt. under the effect of aspirin $(400 \mathrm{mg} / \mathrm{kg} \mathrm{b.w.)} \mathrm{,} \mathrm{Gum}(5 \mathrm{mg} / \mathrm{kg}$ b.w.) and their combination compared with that of the control of male rats. Mean \pm S.E.

\begin{tabular}{|c|c|c|c|c|}
\hline Parameters & Control & Aspirin & Gum & Aspirin+Gum \\
\hline \hline $\begin{array}{c}\text { Body weight } \\
\text { (Mean } \pm \text { S.E.) }\end{array}$ & $181.2 \pm 1.91$ & $201.6 \pm 2.64 * * *$ & $166.6 \pm 1.96 * * *$ & $196.0 \pm$ \\
& & & $-3.3 *$ \\
\hline$\%$ Change & - & $+11.3 \%$ & $0.30 \pm$ & $+8.2 \%$ \\
\hline $\begin{array}{c}\text { Intestinal weight } \\
\text { (Mean } \pm \text { S.E) }\end{array}$ & $0.46 \pm 0.0093$ & $0.50 \pm$ & $0.016^{* * *}$ & $0.53 \pm$ \\
\hline$\%$ Change & - & $+7.76 \%$ & $-34.8 \%$ & $+14.22 \%$ \\
\hline $\begin{array}{c}\text { Mucosal total } \\
\text { protein/intestinal wt. } \\
\text { (Mean } \pm \text { S.E.) }\end{array}$ & $24.7 \pm 0.49$ & $34.6 \pm 1.94 * * *$ & $20.0 \pm 0.76^{* * *}$ & $29.4 \pm$ \\
\hline$\%$ change & - & $+40.08 \%$ & $-19.03 \%$ & $+19.03 \%$ \\
\hline
\end{tabular}

*Significant at $\mathrm{P}<0.05$, ** high significant at $\mathrm{P}<0.01$, ***very highly significant at $\mathrm{P}<$ 0.001 and n.s. represent a nonsignificant respectively. 

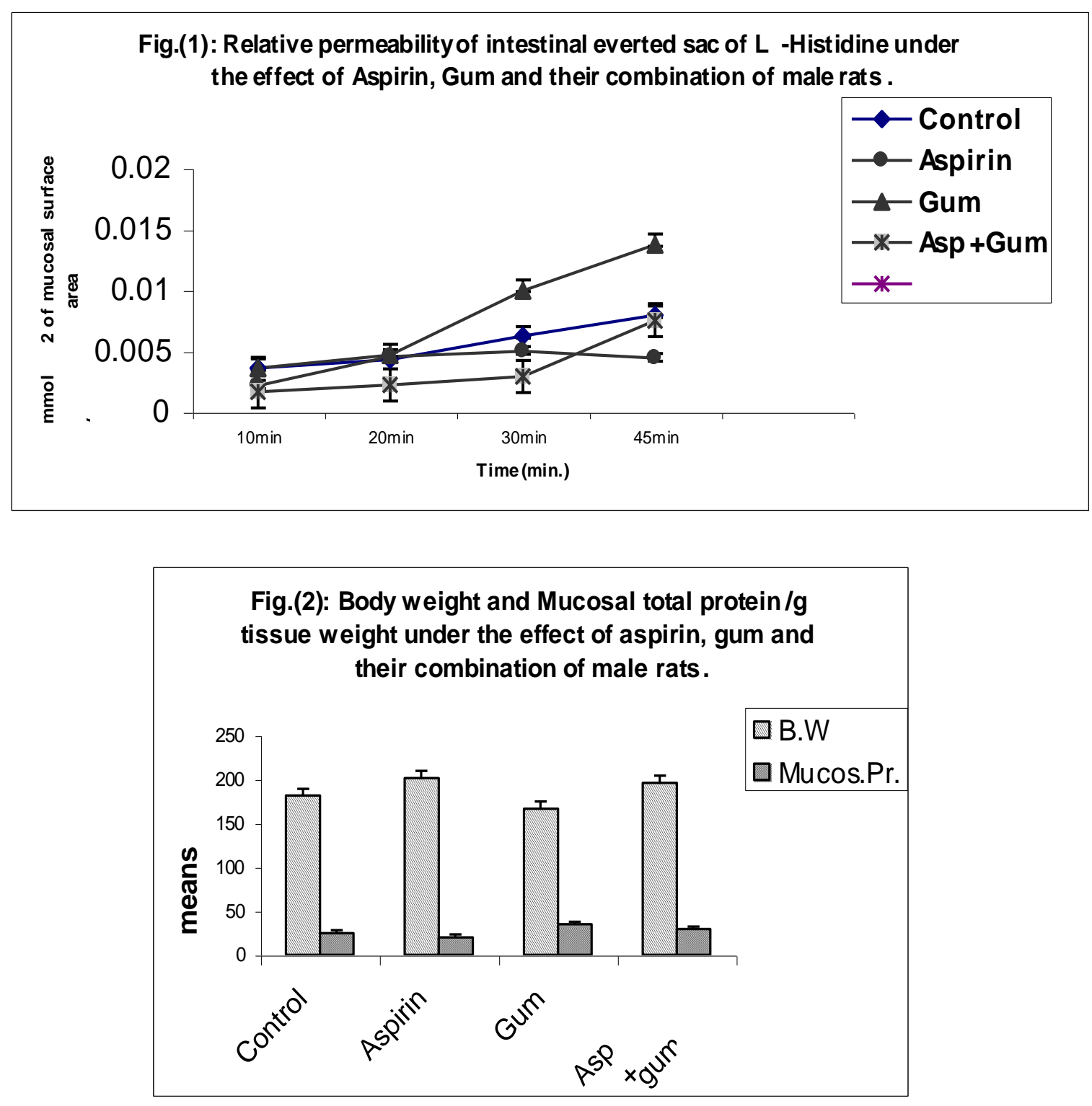

Fig.(3): Intestinal weight $0 \mathrm{~cm}$ length under the effec of aspirin, gum and their combination in male rat

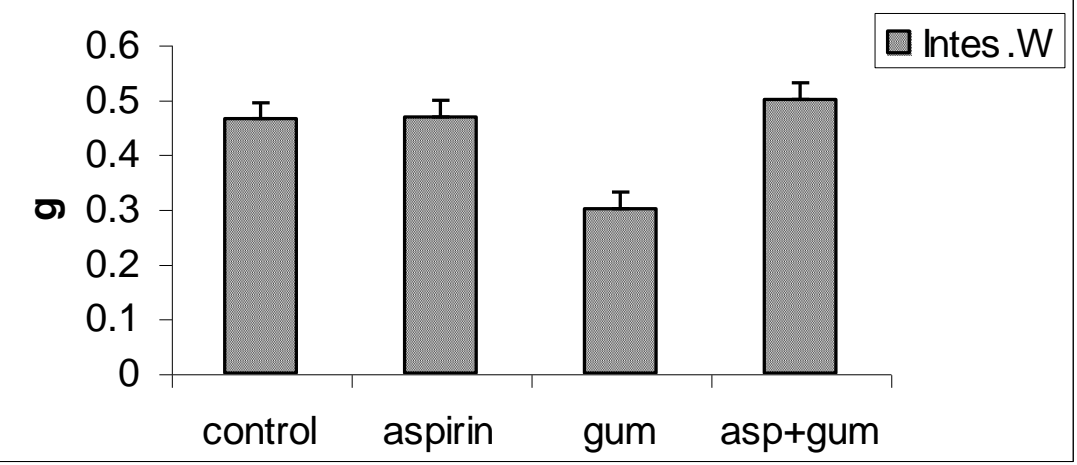




\section{Mahmoud Rabeh Mahmoud}

\section{Results And Discussion}

The effect of aspirin ( $400 \mathrm{mg} / \mathrm{kg}$ body weight), gum and their combination on everted sac permeability is shown in (Table 1-5) and (Figure 1 ). Aspirin transport was significantly $(\mathrm{p}<0.001)$ increased above control levels at $10 \mathrm{~min}$ of incubation compared with that of the control. However, when the longer time (45 min) was used, permeability during this time was significantly $(\mathrm{p}<0.01)$ reduced below control levels. Control values were $0.00356 \pm 0.00018, \quad 0.0043 \pm 0.00042$, $0.0062 \pm 0.00041$ and $0.0079 \pm 0.00078$ $\mathrm{mmol} / \mathrm{cm}^{2}$ surface area at times $10,20,30$ and 45 minuts of incubation respectively. The relative permeability of L-histidine under the effect of gum acacia were increased significantly at $10 \mathrm{~min}(\mathrm{p}<0.01)$ and $30 \mathrm{~min}(\mathrm{p}<0.001)$ above the control values. On the other hand, relative permeability of L-histidine under the effect of aspirin in combination with gum were reduced significantly $(\mathrm{p}<0.001)$ at $10 \mathrm{~min}$, $20 \mathrm{~min}$ and $30 \mathrm{~min}$ of incubation respectively. Body and intestinal weights increased during the treatment of aspirin and aspirin in combination with gum and represented $11 \%, 8 \%, 7.7 \%$ and $14 \%$ respectively These were accompanied with the increase of mucosal total protein in aspirin and aspirin-gum groups by $40 \%$ and $19 \%$ respectively. On the other hand, gum treatment decreased body, intestinal weights and mucosal total protein significantly with percent changes ranged from $8 \%$ to $35 \%$ compared with that of the control (Table 6 and Figurs 2 -3).

The small intestine is the organ for nutrient absorption, which consists of digestion/metabolism and transport. Although the digestion/metabolism of dietary protein or peptides or oligo- or polysaccharides is required for absorption. medicinal drugs must be transported to systemic circulation without metabolic degradation to perform their pharmacological action. Membrane transportability is also expected to be low, since these compounds are hydrophilic and their molecular sizes are large. Therefore, the estimation of each process (metabolism and transport) is required for the evaluation of intestinal absorption. For the kinetic analysis of intestinal absorption, we proposed the metabolic inhibition model (Mizuma et al.,1996; Mizuma et al 1997), which can evaluate the intestinal absorption of analgesic peptides, leucine enkephalin and kyotorphin. The everted intestinal sac has been utilized for many years to study both absorption and permeability characteristics of intestinal tract. It has been modified over time to permit studies to be conducted on carbohydrate absorption (Crane and Wilson, 1958), drug absorption (Chowhan and Amoro, 1977) and permeability to other large molecules (Carter et al.,1990). Recently, Barthe et al.(1998) and Anand et al.(2004) reprted an improved method with greater viability of the sacs using cell culture medium rather than buffers for incubation and loading of the sacs.

Rats exposed to the aspirin diet gained weight normally when compared with rats on the control diet, and no ulceration or intestinal pathology such as perforation of the intestine was observed in any of the rats treated with aspirin. Two independent analyses were performed ( Sansom et al.,2001). L-Histidine, an essential amino acid, is a precursor of histamine, an inflammatory mediator in the lung. Histamine activates local target cells and tissues, such as endothelial cells, fibroblasts, and smooth muscle (Hill,1990). L-Histidine uptake was a saturable process. Furthermore, addition of DNP or rotenone reduced the uptake rate of L-histidine, demonstrating that Lhistidine uptake is metabolic energy dependent. Ouabain, an inhibitor of $\mathrm{Na}^{+}-\mathrm{K}^{+}$ATPase, which is localized in the antiluminal membrane (Betz et al.,1980), also inhibited uptake of L-histidine, possibly by reducing the sodium gradient and membrane potential. The effect of ouabain suggested that one of the driving forces for L-histidine transport is $\mathrm{Na}^{+}$, since choline did not substitute for $\mathrm{Na}^{+}$. These results suggested that L-histidine is actively taken up by a carrier-mediated mechanism with 
energy supplied by $\mathrm{Na}^{+}$. Although the pathogenic events of NSAID induced gastrointestinal damage are controversial, there is a consensus that there is an important "topical" component of the damage both in the stomach and small intestine (Ivey et al.,1980; Ligumsky et al.,1982; Whittle,1992a) which is independent of NSAID action to inhibit cyclooxygenase (Baskin et al., 1976; Somasundaram et al.,1997) .

The dual action of NSAIDs to uncouple oxidative phosphorylation-inhibit electron transport ("topical" action) and inhibit cyclooxygenase ("topical" and systemic action) provides a logical explanation for the mechanism and high prevalence of gastrointestinal toxicity of these drugs. Hence, uncoupling/inhibition following indomethacin (the precise site of absorption is in part determined by size, lipid solubility and charge of the NSAID, drug formulation, gastric $\mathrm{pH}$, etc.) would result in diminished cellular ATP production, cellular calcium toxicity (Carefoli, 1987) , production of reactive oxygen species (Somasundaram et al.,1995) resulting in increased mucosal permeability (Bjarnason et al.,1989; Matthews et al., 1994). Increased intestinal permeability allows luminal aggressive factors access to the mucosa which results in an inflammatory reaction. The concomitant inhibition of cyclooxygenase (which occurs at picomolar concentrations of NSAIDs and hence evident irrespective of the mode of administration of the drugs), with decreased prostaglandins, may then alter local blood flow and therefore be an important cofactor in driving the inflammation to ulcers (Whittle,1992b; Somasundaram et al.,1995). Moreover, in an animal study, consumption of gum acacia stimulated intestinal and splenic immune system function (Eastwood et al.1986). The increases in absorptive capacities of protein by mucosal intestine is decleared by the growth of intestinal weight where this explanation was agreed with Buddington et al., 2001 explanation. Also, Ganapathy et al.(1994) indicated that the majority of dietary amino acids is apparently absorbed as component of peptides. Edwards et al.(1987) investigated the acute effects of guar gum on the bioavailability and utilization of dietary protein and to consider the possibility that gum might acutely modulate urea kinetics in humans. The viscosity of the meal was increased 100fold, probably even more after ingestion because guar-gum-induced viscosity may develop in the stomach and may resist dilution and reneutralization more than viscosity induced by other gums .

Some studies reported that viscous fiber increases the gastric or intestinal secretion of fluids, specifically nitrogen, which indicates that guar gum may activate the upper intestinal disposal of urea ( Marciani et al.,200 Rainbird and Low, 1986; Ehrlein and Stockmann,1998; Stephen and Cummings, 1979).

In this experiment, in the treatment of aspirin at $(400 \mathrm{mg} / \mathrm{kg}$ b.w.) dose resulted in a progressive decrease in L-histidine uptake. This result also, suggested that gum acacia plays an important role in L-histidine uptake into rat intestinal everted sac. In summary, we have shown that dietary aspirin exposure can suppress permeability in the intestine. This effect seems to be specifically associated with a loss of function after the longer time of L-histidine incubation. Critically, in the intestine, suppression only becomes apparent if exposure covers the period between $30 \mathrm{~min}$ and $45 \mathrm{~min}$ of incubation after the saturated intestinal everted sac cells with L-histidine at $10 \mathrm{~min}$ of incubation.

\section{References}

1. Abdel Salam OME, Mószik G, Szolcsányi J. (1995): Studies on the effect of intragastric capsaicin on gastric ulcer and on the prostacyclin-induced cytoprotection in rats. Pharmacol Res;32:209-15.

2. Alter HJ, Zvaifler MJ, Rath CE. (1971): Interrelationship of rheumatoid arthritis, folic acid and aspirin. Blood;38:405-16.

3. Ambanelli U, Ferraccioli GF, Serventi G, Vaona GL. (1982): Changes in serum and urinary zinc induced by ASA and indomethacin. Scand J Rheumatol;11:63-4.

4. Anand, B. S. , Suresh, K. ; Ashim, K. M.(2004): Pharmacokinetics of Novel Dipeptide Ester Prodrugs of Acyclovir Following Oral Administration: Intestinal 


\section{Mahmoud Rabeh Mahmoud}

absorption and Liver Metabolism._The Journal of Pharmacology And Experimental Therapeutics; 10.1124/jpet.104.069997.

5. Barthe, L.; Woodley, J.F.; Kenworthy, S. and Houin, G.(1998): An improved everted gut sac as a simple and accurete technique to measure paracellular transport across the small intestine. Eur J Drug Metab Pharmacolkinet; 23:313-323.

6. Baskin WN, Ivey KJ, Kraus WJ.(1976): Aspirin-induced ultrastructural changes in human gastric mucosa. Ann Intern Med;85:299-303.

7. Betz, AL, Firth JA, and Goldstein GW. Betz, AL, Firth JA, and Goldstein GW.(1980):Polarity of the blood-brain barrier: distribution of enzymes between the luminal and antiluminal membranes of brain capillary endothelial cells. Brain Res; 192: 17-28.

8. Bjarnason I, Smethurst P, Fenn GC, Lee CF, Menzies IS, Levi AJ.(1989): Misoprostol reduces indomethacin induced changes in human small intestinal permeability. Dig Dis Sci;34:407-411.

9. Brookes PM, Day RO.(1991): Nonsteroidal antiinflammatory drugs differences and similarities. $N$ Eng $J$ Med;324:1716-1725.

10. Brune K, Schwietzer A, Eckert H.(1977): Parietal cells of the stomach trap salicylates during absorption. Biochem Pharmacol;26: 1735-1740.

11. Buddington, R.K.; Elnif, J.; PuchalGardinerA.A., and Sangild,P.T. (2001): Intestinal apical amino acid absorption during development of the pig. Am J Physiol Regal Integr Comp Physiol; 280:R241-R247.

12. Buist RA.(1984): Drug-nutrient interactions an overview. Intl Clin Nutr

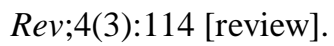

13. Carlson, A. J. \& Hoelzel, F. (1948) Prolongation of the life span of rats by bulking agents in the diet, J. Nutr., 36, 27 40

14. Carter,E.A.; Tompkins, R.G.; Schiffrin, E. and Burke, J.F.(1990): Cutaneous thermal injury alters macromolecular permeability of rat small intestine. Surgery; 3:335-341.

15. Chowhan, Z.T. and Amoro, A.A.(1977): Everted rat intestinal sacs as an in vitro model for assessing absorptivity of new drugs. J Pharm Sci; 66: 1249-1253.

16. Coffey G, Wilson C.W.M.(1975): Ascorbic acid deficiency and aspirininduced haematemesis. $B M J ; \mathrm{I}: 208$.
17. Coimbra-Filho, A.F. and Mittermier, R.A., (1978). "Tree-gouging, Exudateeating and the Short-tusked Condition in Callithrix and Cebuella," In The Biology and Conservation of the Callitrichidae, Devra Kleiman, ed. Smithsonian Institution Press, pp. 105-115.

18. Crane,R.K. and Wilson, T.H. (1958): In vitro method for the study of the rate of intestinal absorption of sugars. J Appl Physiol; 12: 145-146.

19. Cui,X.L.; Soteropoulos,P.; Tolias,P. and Ferraris,R.P.(2004): Fructose-responsive genes in the small intestine of neonatal rats. Physiol Genomics;18(2): 206 - 217.

20. Daneshmend TK, Stein AG, Bhaskar NK, Hawkey CJ. (1991): Abolition by omeprazole of aspirin induced gastric mucosal injury in man. Gut;31:514-517.

21. Dihlmann S., Siermann A., Doeberitz M. V. (2001): The nonsteroidal antiinflammatory drugs aspirin and indomethacin attenuate $\beta$-catenin/TCF-4 signaling. Oncogene; 20: 645-653.

22. Eastwood MA, Brydon WG, Anderson DM. (1986): The effect of the polysaccharide composition and structure of dietary fibers on cecal fermentation and fecal excretion. Am J Clin Nutr;44:51-55.

23. Edwards CA, Blackburn NA, Craigen L. (1987): Viscosity of food gums determined in vitro related to their hypoglycemic actions. Am J Clin Nutr;46:72-7.

24. Ehrlein H, Stockmann A. (1998): Absorption of nutrients is only slightly reduced by supplementing enteral formulas with viscous fiber in miniature pigs. J Nutr;128:2446-55.

25. Fenselau C. (1997). MALDI MS and strategies for protein analysis. Analytical Chemistry; 69:661A-665A.

26. Fiorucci,S. ; Annarita; D. L., Barbara, R.; Silvana, F.; Antonio M.;Giuseppe,C.(2004): Nitric oxide (NO)releasing naproxen (HCT-3012) interactions with aspirin in gastric mucosa of arthritic rats reveals a role for aspirintriggered lipoxin, prostaglandins and NO in gastric protection. The Journal of Pharmacology And Experimental Therapeutics ; 10.1124/jpet.104.072843.

27. Fleagle, J.G., (1988). Primate Adaptation and Evolution. Academic Press Inc., New York.

28. Ganapathy, V.; Bransch, M. and Leibach, F.H.(1994): Intestinal transport of amino acids and peptides. In: Physiology of the Gastroenterol Tract, edited by 
Johnson L.R., New York: Raven,chapt.; 52,p.1773-1794.

29. Garber, P., (1984). "Use of Habitat and Positional Behavior in a Neotropical Primate, Saguinus oedipus," In Adaptations for Foraging in Nonhuman Primates: Contributions to an Organismal Biology of Prosimians, Monkeys and Apes, P.S. Rodman and J.G.H. Cant, eds. New York, Columbia University Press, pp. 112-133.

30. Gisolfi, C.V.(2000): Is the GI system built for exercise? NIPS; 15:114-119.

31. Hill, SJ. (1990): Distribution, properties, and functional characteristics of three classes of histamine receptor. Pharmacol Rev; 42: 45-83.

32. Holzer P, Pabst MA, Lippe IT.(1989): Intragastric capsaicin protects against aspirin-induced lesion formation and bleeding in the rat gastric mucosa. Gastroenterology;96:1425-33.

33. Hundal, HS, Rennie MJ, and Watt PW.(1987): Characteristics of L-glutamine transport in perfused rat skeletal muscle. J Physiol; 393: 283-305.

34. Ivy, A.C. \& Isaacs, B.L. (1938). Karaya gum as a mechanical laxative. An experimental study on animals and man. Am. J. dig. Dis.; 5: 315-321.

35. Ivey KJ, Poane DB, Krause WJ. (1980): Acute effect of systemic aspirin on gastric mucosa in man. Dig Dis Sci;25:97-99.

36. Karasov, W. H., and Diamond, J.M. (1983): A simple method for measuring intestinal solute uptake in vitro. J. Comp. Physiol [B]; 152: 105-116.

37. Kharasch, E.D.; Christine H., C., T. Gul A.,and Dale Whittington, B.S. (2004): Quinidine as a Probe for the Role of PGlycoprotein in the Intestinal Absorption and Clinical Effects of Fentanyl . Journal of Clinical Pharmacology; 44:224-233.

38. Kilberg, MS, Handlogten ME, and Christensen HN.(1980): Characteristics of an amino acid transport system in rat liver for glutamine, asparagine, histidine and closely related analogs. J Biol Chem 255: 4011-4019.

39. Lambert, G.P.; Broussard, L.J.; Mason, B.L.; Mauermaun, W.J. and Gisolfi, C.V. (2001): Gastrointestinal permeability during exercise: effect of aspirin and energy-containing beverages. J Appl Physiol; 90: 2075-2080.

40. Lambert,G.P.; Gisofi, C.V.; Berg, D.J.; Moseley, P.L.; Oberley, L.W. and Kregel, K.C. (2002): Molecular biology of thermoregulation selected contribution:
Hyperthermia induced intestinal permeability and the role of oxidative and nitrosative stress. J Appl Physiol; 92:1750-1761.

41. Langenbach R, Morham SG, Tiano HF, Loftin CD, Ghanayem BI, Chulada PC, (1995):Prostaglandin synthase 1 gene disruption in mice reduced arachidonic acid-induced inflammation and indomethacin-induced gastric ulceration. Cell;83:483-492.

42. Leach, L, Eaton B, Wescott D, and Firth J. (1995): Effect of histamine on endothelial permeability and structure and adhesion molecules of the paracellular junctions of perfused human placental microvessels. Microvasc Res; 50: 323-337.

43. Levine RA, Petokas S, Nandi J, Enthoven D. (1988): Effects of nonsteroidal anti-inflammatory drugs on gastrointestinal injury and prostanoid generation in healthy volunteers. Dig Dis Sci;33:660-666.

44. Ligumsky M, Grossman MI, Kauffman GL. (1982): Endogenous gastric mucosal prostaglandins: their role in mucosal integrity. Am J Physiol;242:G337-G341.

45. Ligumsky M, Golanska EM, Hansen DG, Kauffman GL. (1983): Aspirin can inhibit gastric mucosal cyclo-oxygenase without causing lesions in the rat. Gastroenterology;84:756-761.

46. Low AG, Rainbird AL. (1984): Effect of guar gum on nitrogen secretion into isolated loops of jejunum in conscious growing pigs. Br J Nutr;52:499-505.

47. Lowry, O.H.; Rosebrough, N.J.; Farr, A.L. and Randall, R.J.(1951): Protein measurement with the folin phenol reagent. J. Biol. Chem.; 193:265-275.

48. Marciani L, Gowland PA, Spiller RC, et al. Gastric response to increased meal viscosity assessed by echo-planar magnetic resonance imaging in humans. J Nutr 2000;130:122-7.

49. Mizuma T, Ohta K, Hayashi M, Awazu S. (1992): Intestinal active absorption of sugar-conjugated compounds by glucose transport system: implication of improvement of poorly absorbable drugs. Biochem. Pharmacol.;43:2037-2039.

50. Mizuma T, Ohta K, Koyanagi A, Awazu S. (1996) Improvement of intestinal absorption of leucine enkephalin by sugar coupling and peptidase inhibitors. J. Pharm. Sci.;85:854-857.

51. Matthews JB, Smith JA, Tally KJ, Menconi MJ, Nguyen H, Fink MP. (1994):Chemical hypoxia increases 


\section{Mahmoud Rabeh Mahmoud}

junctional permeability and activates electrogenic ion transport in human intestinal epithelial monolayers. Surgery;116:150-158.

52. Mizuma K, Koyanagi A, Awazu S. (1997) Intestinal transport and metabolism of analgesic dipeptide, kyotorphin: ratelimiting factor in intestinal absorption of peptide as drug. Biochim. Biophys. Acta;1335:111-119.

53. Moynihan, M. (1976). "Notes on the Ecology and Behavior of the Pygmy Marmoset (Cebuella pygmaea) in Amazonian Columbia," In Neotropical Primates - Field Studies and Conservation, R. W. Thorington, Jr. and P.G. Heltne, eds. Washington, D.C., U.S.National Academy of Science Press, pp.; 79-84.

54. Moy, AB, Van Engelenhoven J, Bodmer J, Kamath J, Keese C, Giaever I, Shasby S, and Shasby DM.(1996): Histamine and thrombin modulates endothelial focal adhesion through centripetal and centrifugal forces. J Clin Invest ;97: 1020-1027.

55. Nash, L.T. (1986). "Dietary, Behavioral and Morphological Aspects of Gummivory in Primates," Yearbook of Physical Anthropology; 29:113-137.

56. Pals, K.L.; Chang, R.T.; Ryan, A.J. and Gisolfi, C.V. (1997): Effect of running intensity on intestinal permeability. J Appl Physiol; 82: 571-576.

57. Rainbird AL, Low AG. (1986): Effect of guar gum on gastric emptying in growing pigs. Br J Nutr;55:87-98.

58. Rainsford KD, Whitehouse MW.(1982): Biochemical gastroprotection from acute by aspirin and related drugs. Biochem Pharmacol;29:1281-1289.

59. Rainsford KD. (1989): Mechanisms of gastrointestinal toxicity of non-steroidal anti-inflammatory drugs. Scand J Gastroenterol; 24 (suppl 163): 9-16.

60. Ryan, A.J.; Chang , R.T. and Gisolfi, C.V.(1996): Gastrointestinal permeability following aspirin intake and prolonged running. Med Sci Sport Exerc; 28: 698705.

61. Rees WDW, Rhodes J, Wright JE.(1979). Effect of deglycyrrhizinated liquorice on gastric mucosal damage by aspirin. Scand J Gastroenterol;14:605-7.

62. Rosenberger, A.L. (1978). "Loss of Incisor Enamel in Marmosets," Journal of Mammalogy; 59:207-208.

63. Sakurai, E.; Tomoya S., Yoshinori O.; Jun Y. and Yorihisa T.(2002): Stereoselective transport of histidine in rat lung microvascular endothelial cells . Am J Physiol Lung Cell Mol Physiol; 282: L1192-L1197.

64. Salzman, A. L.; Wang, H.; Wollert, P.S.; Vandermeer, T.J.; Compton, C.C.; Denenberg, A.G. and Fink, M.P. (1994): Endotoxin-induced ideal mucosal hyperpermeability in pigs: Role of tissue acidosis. Am J Physiol Gastrointest.Liver Physiol; 266: G 633-G646.

65. Sansom, O.J; Lesley A. Stark, Malcolm G. Dunlop and Alan R. Clark(2001): Suppression of Intestinal and Mammary Neoplasia by Lifetime Administration of Aspirin in $A p c^{\mathrm{Min} /+}$ and $A p c^{\mathrm{Min} /+}, \mathrm{Msh}^{-/-}$ Mice. Cancer Research; 61, 7060-7064.

66. Sharathchandra, J.N.N.; Kalpana, P. and Srinivasan, K. (1995): Digestive enzymes of rat pancreas and small intestine in response to orally administered mint leaf and garlic oil. Ind J Pharm; 27 :156-160.

67. Shu, R., E. S. David, and R. P. Ferraris (1997): Dietary fructose enhances intestinal fructose transport and GLUT5 expression in weaning rats. Am. J. Physiol. 272 (Gastrointest. Liver Physiol; 35: G446G453.

68. Somasundaram S, Hayllar J, Rafi S, Wrigglesworth J, Macpherson A, Bjarnason I. (1995): The biochemical basis of NSAID-induced damage to the gastrointestinal tract: A review and a hypothesis. Scand J Gastroenterol;30:289-299.

69. Somasundaram, S. S Rafi, J Hayllar, G Sigthorsson, M Jacob, A B Price, A Macpherson, T Mahmod. D Scott, J M Wrigglesworth, I Bjarnaso, (1997): Mitochondrial damage: a possible mechanism of the "topical" phase of NSAID induced injury to the rat intestine GUT; 41:344-353 .

70. Snedecor,G.W. and Cochran, W. (1969): Statistical methods, $6^{\text {th }}$ ed. The Iowa state U.S.A.

71. Sussman, R.W. and Kinzey, W.G. (1984). "The Ecological Role of the Callitrichidae: A Review," American Journal of Physical. Anthropology; 64:419-449.

72. Thomas, G.R.; Thibodeaux,H.; Errett,C.G.; Bednar,M.M.; Gross,C.E. and Gross,W.F. (1993): Intravenous Aspirin Causes a Paradoxical Attenuation of Cerebrovascular Thrombolysis The Pharmacologist;35:275-279.

73. Travis, S. and Menzies, I.( 1992): Intestinql permeability: Functional assessment and significance. Clin. Sci.(Colch); 82: 471-488. 
74. Unno, N.; Wang, H.; Menconi, M.J.; Tytgat, S.H.; Larken, V.; Smith, M.; Morin, M.J.; Chavez, A.; Hodin, R.A. and Fink, M.P. (1997): Inhibition of inducible nitric oxide synthase ameliorates endotoxin induced gut mucosal barrier dysfunction in rats. Gastroentrology; 113:1246-1257.

75. Wallace JL. (1994): The Merk Frost Award. Mechanism of nonsteroidal antiinflammatory drug (NSAID) induced gastrointestinal damage-potential for development of gastrointestinal tract safe NSAIDs. Can J Physiol Pharmacol 72:1493-1498.

76. Whittle BJR. (1992a): Protective mechanisms of the gastric mucosa. In:
Gustsavsson S, Kumar D, Graham DY, eds. The stomach. Edinburgh: Churchill Livingstone;81-101.

77. Whittle BJR.(1992b): Unwanted effects of aspirin and related agents on the gastrointestinal tract. In: Vane JR, Botting RM, eds. Aspirin and other salicylates. London: Chapman and Hall Medical; 465-509.

78. Wu, NZ, and Baldwin AL.(1992): Transient venular permeability increase and endothelial gap formation induced by histamine. Am J Physiol Heart Circ Physiol; 262: H1238-H1247.

79. Yeh, K. Y., and P. R. Holt(1986): Ontogenetic timing mechanism initiates the expression of rat intestinal sucrase activity. Gastroenterology; 90: 520-526. 


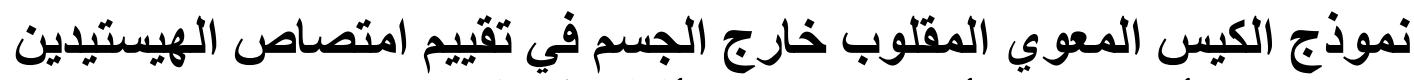 تحت تأثثير عقار الأسبرين وصمغ أقاقيا في ذكور الفئران البيضاء

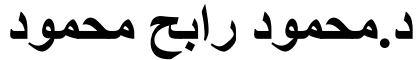

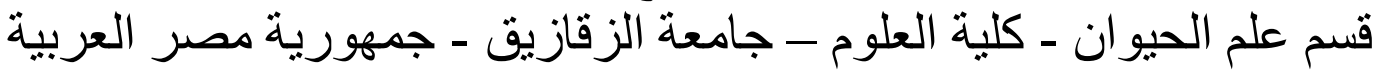

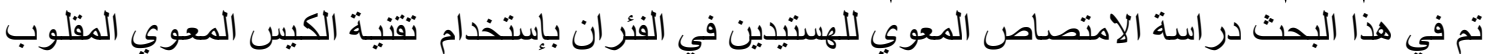

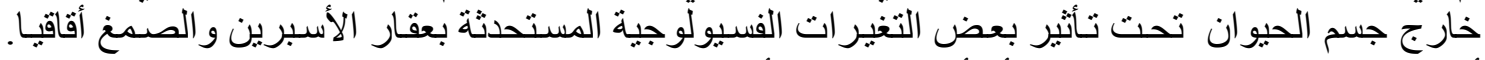

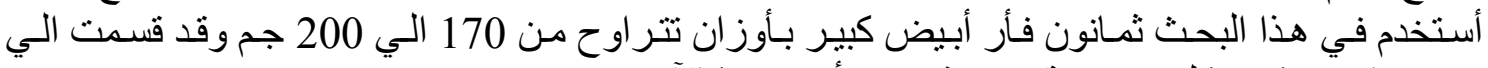

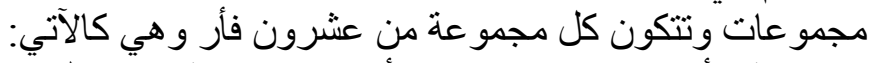

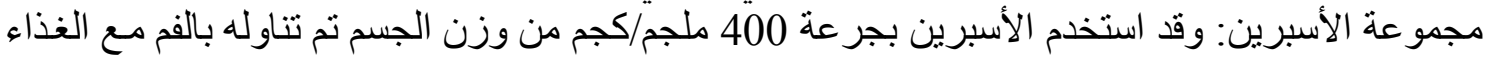
لمدة 21 يوما علي التوالي.

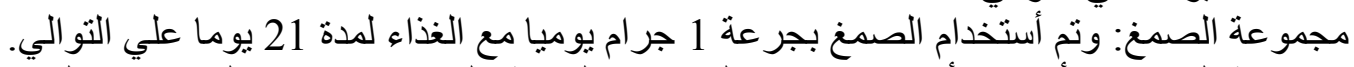

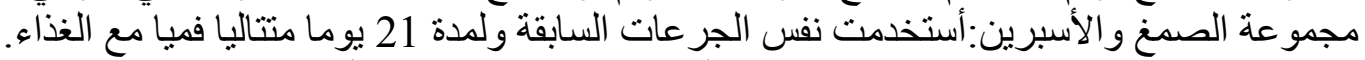
المجمو عة الضابطة: لم ينم في هذه المجمو عة أبي اضافات دو ائية للغذاء أو المات الماء.

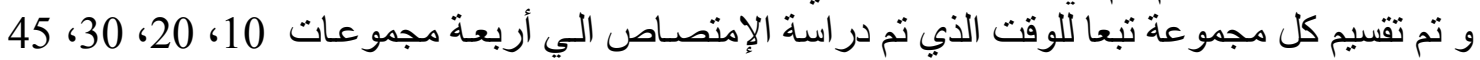

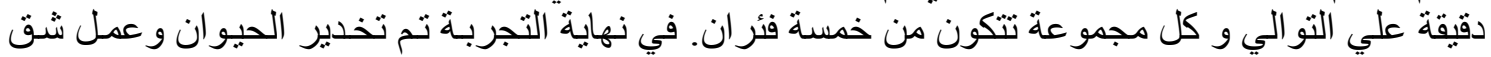

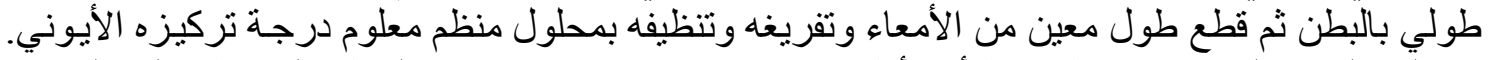

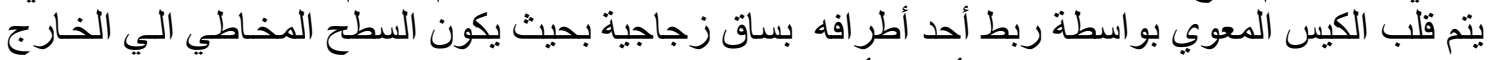

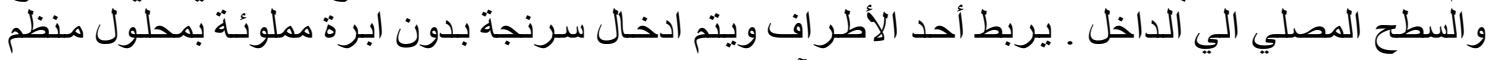

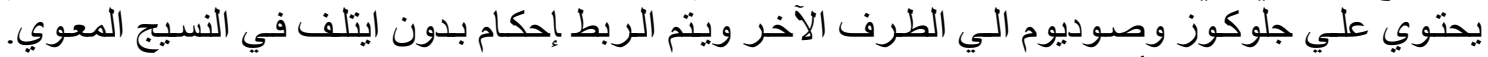

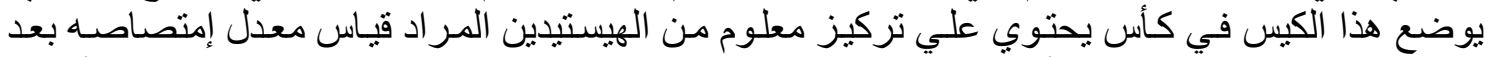

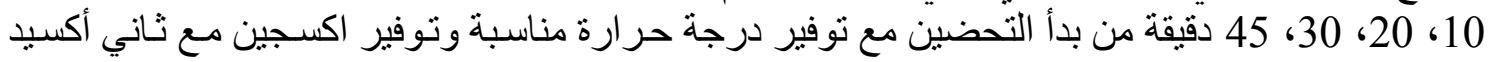

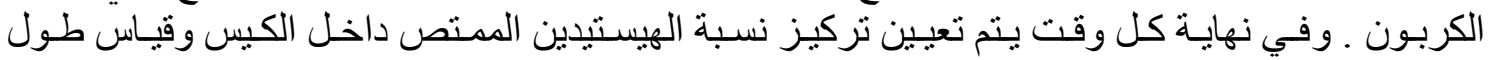

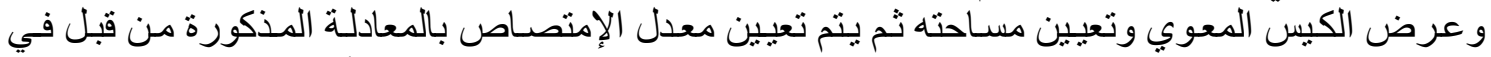

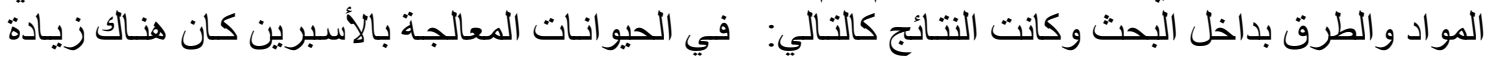

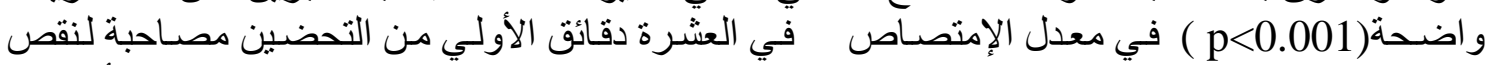

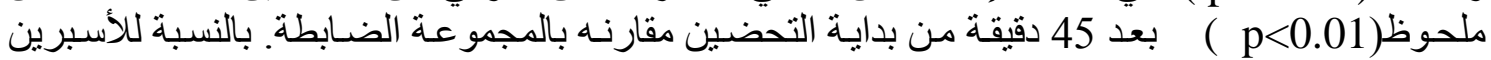

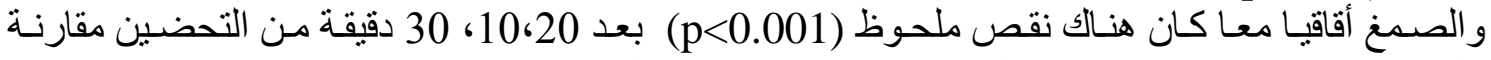

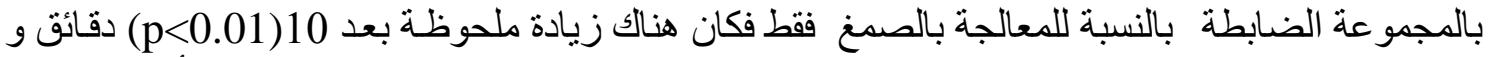

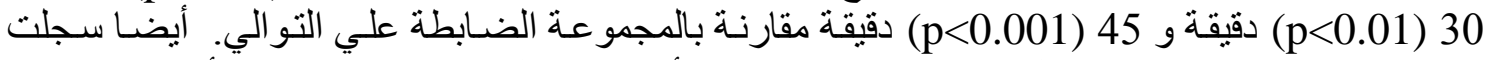

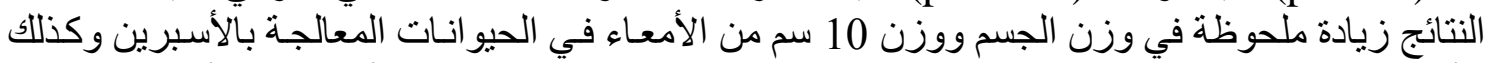

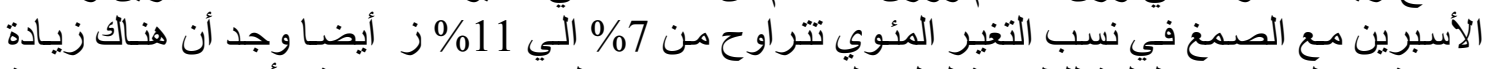

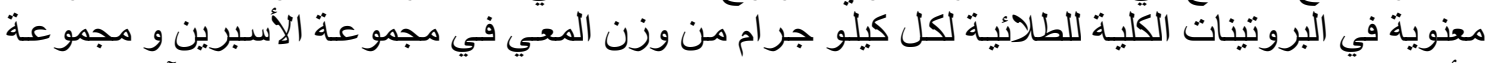

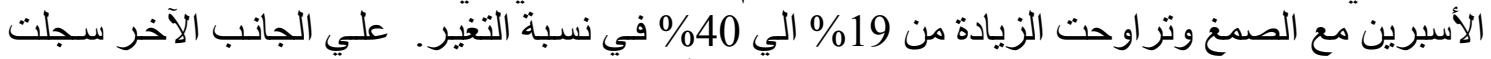

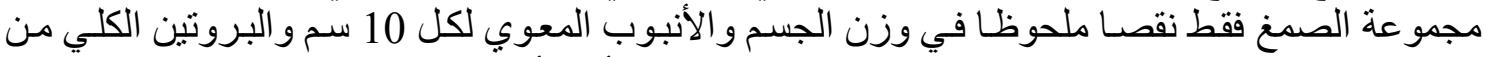

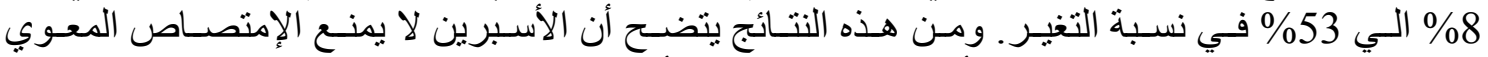

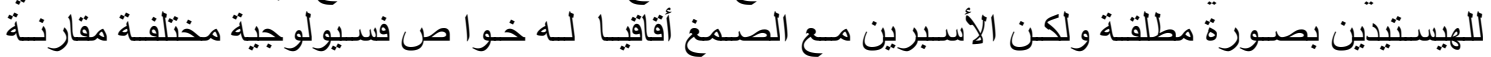
بالمجمو عات الضابطة. 